ROCZNIKI HUMANISTYCZNE

Tom LXVIII, zeszyt $6-2020$

DOI: http://dx.doi.org/10.18290/rh20686-4

JOANNA KAMPER-WAREJKO

JOANNA KULWICKA-KAMIŃSKA

\title{
PERSWAZJA W CZASACH REFORMACJI. RENESANSOWE TEKSTY APOLOGETYCZNE TRZECH KONFESJI: KATOLICYZMU, PROTESTANTYZMU I ISLAMU
}

\section{PRĄDY UMYSŁOWE RENESANSU: HUMANIZM I REFORMACJA}

Perswazja ${ }^{1}$, czyli oddziaływanie polegające na przekonywaniu odbiorcy do głoszonych poglądów, zaakceptowania cudzych sądów i racji, prowadzące do zmiany sposobu myślenia i zachowania to podstawowy składnik sztuki retorycznej. Jako metoda wywierania wpływu na wiernych była powszechnie wykorzystywana również w czasach reformacji, nie tylko przez innowierców. Jej nadrzędną funkcją jest bowiem funkcja nakłaniająca. Według współczesnej nauki perswazja to element socjotechniki, rozumianej jako sposób wywierania wpływu prowadzący do zmiany w społeczeństwie (Karwat 17; por. Zwoliński 257; Podgórecki). W „komunikacji perswazyjnej można znaleźć wiele przykładów, gdzie refleksja etyczna wydaje się być nieodzowna i konieczna" (Krok 185). Taka refleksja może również towarzyszyć analizie dawnych polemicznych tekstów religijnych. Przyjrzenie się sposobom argumentowania, przedstawiania faktów, językowym wykładnikom przekazywania treści służących zmianie postaw może ukazać pewne nadużycia etyczne.

Dr hab. JOANNA KAMPER-WAREJKo, prof. UMK - adiunkt w Katedrze Języka Polskiego UMK; adres do korespondencji: Uniwersytet Mikołaja Kopernika, Instytut Językoznawstwa, Fosa Staromiejska 3, 87-100 Toruń; e-mail: asiakw@umk.pl; ORCID: https://orcid.org/0000-0001-9877-6242.

Dr hab. JOANNA KULwiCKA-KAMiŃSKA, prof. UMK - adiunkt w Katedrze Języka Polskiego UMK; adres do korespondencji: Uniwersytet Mikołaja Kopernika, Instytut Językoznawstwa, Fosa Staromiejska 3, 87-100 Toruń; e-mail: Joanna.Kulwicka-Kaminska@umk.pl; ORCID: https://orcid.org/ 0000-0001-8566-9181.

${ }^{1}$ Pojęcie to wywodzi się z łacińskiego rzeczownika persuasio 'przekonanie, wiara, opinia, uspokojenie, przesąd, łagodność' i czasownika persuadere (gr. peito) oznaczającego m.in. 'nakłanianie, namawianie, przekonywanie, oczarowanie' (za Korolko 28). 
Niniejsze opracowanie wpisuje się w nurt badań nad leksyką i frazeologią polskiej reformacji. Poza kilkoma monografiami (m.in. Kwilecka; Winiarska; Meller; Kamper-Warejko; Koziara; Lisowski; Hawrysz; Kulwicka-Kamińska) i licznymi artykułami podejmującymi tę problematykę wciąż odczuwa się niedosyt opracowań doby średniopolskiej, która dla rozwoju słownictwa i frazeologii religijnej miała fundamentalne znaczenie. Powstanie literatur europejskich, opartych na językach narodowych, w tym na języku polskim, jest bowiem niewątpliwie zasługą ruchu reformacyjnego i humanizmu. Reformacja protestancka, która od początku XVI wieku objęła niemal całą Europę, była czymś więcej niż reformą chrześcijaństwa, „chciała być niejako powtórnym powstaniem chrześcijaństwa i powrotem do tego, co w jej pojęciu stanowiło samą jego istotę" (Witczyk 631). Zerwanie z tradycją i opowiedzenie się za zasadą doktrynalną sola Scriptura prowadziło do (niekiedy zażartych) sporów dogmatycznych (Lisowski 14). Elżbieta Belcarzowa pisała: „Szerzące się coraz bardziej koło połowy XVI w. różnowierstwo, zdobywające sobie zwolenników m.in. pismami w języku polskim, mobilizowało do przeciwdziałania obóz katolicki” (7).

Kontrakcja katolicka poszła dwiema drogami: pism łacińskich i piśmiennictwa wyłącznie w języku polskim, przeznaczonego dla jak najliczniejszych odbiorców i uderzającego w pisma innowierców. Stąd też walka katolików $\mathrm{z}$ różnowiercami toczyła się w połowie XVI wieku przeważnie w języku polskim i przyczyniła się do powstania przekładów biblijnych w tymże języku. Zarówno bowiem pisma różnowiercze, jak i odpowiedzi na nie katolików, znaczną część argumentów i kontrargumentów czerpały właśnie z Pisma Świętego, stąd też ,pełno w nich cytatów nie tylko z Nowego Testamentu, ale i z ksiąg starotestamentowych" (Lisowski 8-9). Polemiki religijne powodowały laicyzację języka religii, wpływały na rozwój języka ogólnego i stylu retorycznego, a także na doskonalenie mechanizmów perswazji językowej. W XVI wieku powstawały nowe formy piśmiennictwa okołobiblijnego, podejmującego problematykę teologiczną, np. konfesje, katechizmy, postylle, apologie, kancjonały, śpiewniki, kazania. Kontakty międzywyznaniowe, w tym również polemiczne, miały też znaczący wpływ na literaturę przekładową. Do bezpośrednich następstw ruchu reformacyjnego można zatem zaliczyć: ogólny rozwój języka narodowego, tworzenie piśmiennictwa religijnego $\mathrm{w}$ językach narodowych, liberalizację języka religijnego połączone $\mathrm{z}$ awansem języka narodowego, uzyskanym dzięki wprowadzeniu go do liturgii, a także prowadzeniu $\mathrm{w}$ nim polemik i dysput na temat wiary (tu m.in. powstanie i rozwój specyficznego słownictwa i frazeologii), praktycyzm, dąże- 
nie do aktywizacji wiernych, wdrażanie ich do lektury Pisma Świętego i związaną z tym alfabetyzację wiernych (Kulwicka-Kamińska 79, 83).

Ten nowy typ chrześcijaństwa, jak już wspomniano, rozwinął się też w Polsce, szczególnie pod rządami tolerancyjnych Jagiellonów (1507-1572). Wielu wybitnych i znanych pisarzy i działaczy doby średniopolskiej to przedstawiciele luteranizmu (np. Jan Seklucjan), kalwinizmu (np. Jan Łaski) i radykalnych odłamów protestanckich, takich jak bracia polscy (np. Jan Siemieński) i czescy (np. Jan Amos Komenski) (Witczyk 631-633).

Z głównych prądów umysłowych renesansu wyrasta również piśmiennictwo religijne Tatarów Wielkiego Księstwa Litewskiego (WKL), którzy opierali swoją autonomię na własnej historii, kulturze i religii ${ }^{2}$. Na kontekst kulturowy powstania muzułmańskich tłumaczeń religijnych wskazuje w swoich pracach m.in. Paul Suter, który wśród głównych przyczyn ich genezy wymienia: humanizm, reformację, rozwój polskiego języka literackiego, powstanie przekładów Biblii na języki narodowe, w tym na język polski, polonizację Tatarów w WKL, wpływy kalwinów i antytrynitarzy (Suter 94-104). Michaił Tarełka oraz Iryna Synkowa wśród czynników sprawczych powstania piśmiennictwa muzułmanów litewsko-polskich wymieniają: wpływy humanizmu, a głównie rozwoju nauk humanistycznych i filologicznych - nie tylko języka łacińskiego, ale także greki i hebrajskiego oraz powstanie krytycznych studiów tekstów biblijnych, rozwój biblistyki, zwrócenie uwagi na problematykę biblijną i religijną, skrupulatną analizę oryginalnych tekstów i czerpanie z nich argumentów polemicznych. Wskazują także na ruch reformacyjny, a szczególnie na krytykę Kościoła rzymskokatolickiego, która otworzyła drzwi dla szerokiej i otwartej dyskusji na temat religii, wiary, życia według jej zasad etc. W krytyce i polemikach religijnych Tatarzy wykorzystywali przekłady Biblii na języki narodowe, m.in. Biblię nieświeska, Biblię brzeska, Biblię Wujka, oraz egzegetykę, katechizmy, literaturę dydaktyczną i polemiczną. Szczególnie bliskie były im poglądy antytrynitarzy wiążące się ze skrajnym monoteizmem, obecnym także $\mathrm{w}$ islamie, ale i w judaizmie, stąd w piśmiennictwie tatarskim powoływanie się na poglądy arian (Тарэлка і Сынкова 308) i szczególne wpływy radykalnego antytrynitarza Szymona Budnego. Literatura religijna Tatarów WKL odzwierciedla jednakże nie tylko wpływy reformacji, ale także kontrreformacji, ponieważ w drugiej połowie XVI wieku osłabiony reformacją Kościół katolicki podjął działania kontrreformacyjne - apologetyczne, co dotknęło także muzułmanów (por.

\footnotetext{
${ }^{2}$ Rola reformacji i kontrreformacji w genezie tatarskiej literatury religijnej (za Kulwicka-Kamińska 80-81).
} 
paszkwile - Al-Koran z 1616 r. i Al-Furkan z 1617 r. Piotra Czyżewskiego). Autorzy pracy Адкуль пайшлі ідаль wskazują zatem na próby podejmowania obrony swojej wiary przez Tatarów m.in. poprzez wykorzystywanie tekstów historycznych, np. tekstu protestanckiego autora w obronie Jana Husa (Тарэлка і Сынкова 311), krytykę bałwochwalstwa, jego obecności i praktykowania w chrześcijaństwie (w tym dogmatu o Trójcy Świętej i uznawaniu boskiej natury Jezusa), krytykę tradycyjnej chrześcijańskiej egzegezy etc. (Тарэлка і Сынкова 316-338).

\section{PRZEDMIOT I ŹRÓDŁA BADAŃ}

Przedmiotem opisu jest język religijny doby renesansu. W badaniach zwrócono uwagę na tematykę literatury reformacyjnej i jej wymiar wspólnotowy, mający na celu scalanie wspólnoty wierzących. Ponadto wskazano oparty na zasadzie sola Scriptura - prymat Pisma Świętego wobec Tradycji i Magisterium.

Bazą materiałową są zatem XVI-wieczne teksty religijne. Należą do nich kazania, reprezentujące dwa odłamy chrześcijaństwa. Oba teksty ukazały się drukiem w 1595 roku, jednym z nich jest protestanckie kazanie Piotra Artomiusza pt. Sermon to jest kazanie na dzień Wniebowzięcia Panny czystej, ktory się co Rok 15. Augusti wraca ${ }^{3}$, drugim - napisane na tę samą okazję katolickie kazanie Piotra Skargi pt. Na Dzień Wniebowzięcia Przeczystej Matki Bożej (Skarga 599-605)4. Przeznaczenie tych dwóch kazań na jedno ze świąt roku kościelnego sprawia, że w ich warstwie treściowej odnajdujemy wiele podobieństw (por. Kamper-Warejko, „Treściowe i językowe wykładniki podejścia do kultu Maryi w protestanckim kazaniu na święto Wniebowzięcia NMP (Artomiusz 1595)"). Obydwa bezpośrednio nawiązują do Ewangelii św. Łukasza (10,38-42), jej fragment zamieszczono przed każdą z homilii.

Podstawowa definicja kazania jako gatunku głosi, że jest ono przemówieniem religijnym wygłaszanym przez kapłana w trakcie stałych bądź okolicznościowych uroczystości liturgicznych [...], wykłada podstawy wiary bądź przekazuje nauki moralne (Głowiński 240, por. Witczyk 243). Celem mowy kaznodziejskiej jest zainteresowanie i przekonanie odbiorcy do głoszonych

\footnotetext{
${ }^{3}$ Zabytek przechowywany jest w Bibliotece Narodowej (z sygnaturą Baw.24045). Ukazał się w toruńskiej oficynie Andrzeja Koteniusza u schyłku stulecia i w całości liczy 35 stron.

${ }^{4}$ Dzięki uprzejmości pracowników toruńskiego oddziału Pracowni Słownika Polszczyzny $\mathrm{XVI}$ wieku, korzystamy z egzemplarza, będącego w zbiorach pracowni.
} 
prawd. Ważnym aspektem jest również oddziaływanie na emocje słuchacza, kazanie powinno poruszyć i nakłonić do określonego postępowania. Stawiane przed taką mową zadania impresywne realizowane były przy użyciu różnorodnych figur retorycznych ${ }^{5}$. Uwagę skupiono zatem na środkach językowych wykorzystanych $\mathrm{w}$ celu przedstawienia i obrony głoszonych $\mathrm{w}$ tekstach prawd wiary oraz zabiegach, które służą przekonaniu do nich odbiorcy.

Teksty polemiczne, o charakterze perswazyjnym są także obecne w różnych typach tatarskiego piśmiennictwa, a zwłaszcza w tzw. księgach podstawowych, czyli np. w tefsirach, kitabach, chamaiłach ${ }^{6}$. Częścią tych ostatnich są m.in. chutby, które w tradycji rękopiśmiennej Tatarów WKL pełnią funkcję tekstów kaznodziejskich ${ }^{7}$. Wykraczają one jednak poza klasycznie rozumiany gatunek literacki, jakim jest kazanie. Są formą wypowiedzi z pogranicza modlitwy i oracji oraz stanowią składnik centralny nabożeństw świątecznych (Drozd 57) ${ }^{8}$. Oracja do nabożeństwa zawierała dwie części, stanowiące odrębne chutby (Drozd 61). „Temat pierwszej, obszerniejszej, nawiązywał do okoliczności nabożeństwa, niósł aktualne pouczenie dla wiernych, w drugiej zaś skupiał się na modlitwie proroka za monarchę. W zbiorach oracji podawano na okazje kolejnych świąt jedynie teksty pierwszych chutb, teksty drugich były zawsze takie same" (Drozd 61). Obie składały się na jedno wystąpienie oratorskie. W zawartości treściowej chutb można wyróżnić: formułę hamdali ('Chwała niech będzie Bogu'), cytaty z Koranu, szahadę (wyznanie wiary), modlitwę za proroka, wezwanie do pobożności, modlitwę za wiernych i krótkie wystąpienie na aktualny temat ${ }^{9}$. Także współcześnie, podczas kazań piątkowych, recytowany jest Koran. Wystąpienia zawierają inwokacje religijne, np.: „W imię Boga Miłościwego i Litościwego”, „Niechaj modlitwa i pokój będą z Prorokiem” czy „Poszukuję w Bogu schronienia przed szatanem”. Kończą je z kolei frazy: „Nie ma innej mocy i schronienia niż Bóg” oraz "Słowo Boga jest najważniejsze i najwyższe”. Ich uzupełnieniem są cytaty koraniczne gloryfikujące wiarę i wartości muzułmańskie. Inwokacje zostają ponadto rozdzielone charakterystycznym wyrażeniem: „a potem, następnie”, które jest symbolicznym przejściem do zasadniczej

${ }^{5}$ Por. figury retoryczne i retoryka (Okopień-Sławińska 154-155, 472-473), (Sambor 59).

${ }^{6}$ Według ustaleń kitabistów tatarska literatura przekładowa powstała w 2. połowie XVI wieku. Badacze dysponują jednak późniejszymi kopiami - od XVII do XX wieku.

${ }^{7} \mathrm{~W}$ klasycznym islamie jest to kazanie wygłaszane w meczecie podczas modlitwy piątkowej. Zawiera zarówno treści religijne, jak i odniesienie do wydarzeń bieżących.

${ }^{8}$ Według Dziekana „Początkowo były to wypowiedzi dżahilijskich wieszczków-kapłanów, tzw. kāhinów, jak też różne mowy okolicznościowe, związane z życiem plemienia. Z czasem, po wprowadzeniu islamu, stały się częścią modlitwy zbiorowej w meczecie” (15-16 za Drozd 57).

${ }^{9} \mathrm{~W}$ modlitewnikach Tatarów obejmowały zaledwie kilka zdań (Drozd 62). 
części poruszającej rozmaite zagadnienia teologiczne i społeczne (Styszyński 18). Jednak - jak już wspomniano - nie tylko chutby pełnią funkcję modlitewno-perswazyjną i są bogato inkrustowane fragmentami Koranu w thumaczeniu Tatarów WKL na język polski. Liczne cytaty bądź obszerne fragmenty tego przekładu cechują także takie zabytki rękopiśmienne, jak np. kitaby czy chamaiły. Wykorzystywano je bowiem w dyskusjach religijnych, co było zgodne z klasyczną koncepcją polemiki (ar. ğadal): aby przekonać odbiorcę czerpano z wiarygodnych, szanowanych źródeł, takich jak Koran, hadisy (przypowieści przypisywane Prorokowi Mahometowi), analogie historyczne, cytaty znanych osobistości etc. (Styszyński 17). Z ideą polemiki wiąże się również pojęcie cytowania i odwoływania się do autorytetu (ar. iktibas), które dotyczy cytowania źródeł teologicznych, zwłaszcza wersetów koranicznych pozwalających nadać rangę prezentowanej treści i dobrze ugruntować przesłanie w myślach odbiorcy (Styszyński 17).

Analizie poddano zatem jedną z sur Koranu pt. Wzniesione krawędzie w tłumaczeniu Tatarów WKL ${ }^{10}$. Traktuje ona o prorokach posyłanych do pogan. Obfituje w nominacje osób niewierzących w Boga, a zarazem odrzucających islam. Nazwy te występują również w innych typach tatarskich zabytków. Wśród nich obecne są deskrypcje jednowyrazowe (rzeczownikowe i przymiotnikowe) i wielowyrazowe o znaczeniu pejoratywnym, pochodzące z tłumaczeń Biblii oraz z pism religijno-polemicznych epoki renesansu. Wybrane translaty zestawiono $\mathrm{z}$ oryginałem arabskim celem wskazania funkcji perswazyjnej tefsirowego tłumaczenia.

\section{KAZANIA CHRZEŚCIJAŃSKIE}

\section{A. STRUKTURA I JĘZYKOWE WYKŁADNIKI DIALOGICZNOŚCI KAZAŃ}

Jak już wyżej wspomniano, obydwa chrześcijańskie kazania poprzedzono fragmentem ewangelijnym (Łk 10). Po nim, zarówno u Artomiusza, jak i u Skargi, następuje ukazanie i wyjaśnienie celu kazania. Na końcu duchowni zamieszczają swego rodzaju modlitwę. Mowę do luteranów kończy tekst po łacinie, Skarga natomiast w końcówce kazania wprowadza modlitewne wołanie do Maryi, rozpoczynające się od słów: O Mátko Bogá naszego [...] i kończące się wezwaniem: Uproś nam [...] obroć oczy miłosierne ná nas

\footnotetext{
${ }^{10} \mathrm{~W}$ tatarskim tefsirze - w stosunku do oryginalnego Koranu - może występować przesunięcie o jeden, dwa lub nawet kilka wersetów, czyli np. wersetowi drugiemu oryginału odpowiada werset pierwszy tefsiru itd.
} 
[...] (605). Właściwe kazanie w obu przypadkach składa się z dwóch części, wydzielonych graficznie i tematycznie (Skarga - Pierwsza część [...] 600602 i Wtora część [...] 602-605; Artomiusz - Sermon A verso-C4 verso, II C4 verso-D verso), w których duszpasterze starają się przekonać słuchaczy do swoich racji, powołując się na historie z Biblii, przytaczając wypowiedzi autorytetów Kościoła, Apostołów, Proroków (np. u Artomiusza: upominamy się przykładem i obyczajem Kośćioła pierwszego A3 verso; są tu nawiązania do Apostolá Páwłá S. B verso, przykłady z Ewangelii B2, cytaty ze św. Hieronima, Augustyna, nawiązania do Ewangelii św. Łukasza D; u Skargi: [...] i jáko ja Kośćiol stowy pismá ś.czći, i Doktorowie święći stárożytni sławia (600) - przykłady z Pisma Świętego - aniołowie czczący Maryję; cytaty ze świętych starożytnych i greckich Doktorow, przemawiające za tezami, które stawia 601, też nauki Apostołów, czerpane z Ewangelii, np. ze św. Łukasza, $603)^{11}$. W treści kazań pojawia się przeciwnik w wierze, mówcy już na płaszczyźnie językowej tworzą opozycję my - oni (3-osobowe formy zaimkowe, czasownikowe). Skarga zasadniczą pierwszą część kazania rozpoczyna od słów Ci ludźie [...] (600), to samo - lekko pejoratywne - określenie dla adwersarzy w wierze znajdujemy też u Artomiusza (A4). Ich nauki, postępowanie i przytaczane argumenty są na ogół charakteryzowane czasownikowymi formami 3. os. 1. mn. i 1. poj., o czym będzie jeszcze mowa poniżej.

Już w początkowej części obu homilii w warstwie językowej ujawnia się nadawca wypowiedzi, utożsamiany tu z kaznodzieją. Obaj duchowni najczęściej używają w tej funkcji czasownikowych form 1. os. 1. mn. i form zaimka osobowego $m y^{12}$. Wprowadzają słuchacza $\mathrm{w}$ tematykę kazań i w dalszych częściach tekstów piszą:

Artomiusz, np. zajźrzemy, pamiątę jej oddawamy, przyznawáć [...] mamy (A verso), przystapiemy, obchodziem, dotkniem (B verso), upominamy się [...] czyniem (B3 verso), dopytamy się (C4), się [...] dowiemy, ogladamy, się cieszyć będziem, uźrzemy, jego miłować i chwalić będziemy (C4 verso), [...] nam przed oczy stawia, uczy nas Wiary [...] záleca nam Wiáre [...] uczyć się mamy [...] chcemyli mieć [...] stucháć musiem (D verso);

${ }^{11}$ Zarówno w kazaniu toruńskiego pastora Piotra Artomiusza, jak i wybitnego jezuickiego kaznodziei Piotra Skargi we fragmentach, w których opowiadają oni o wydarzeniach biblijnych, komentują Ewangelię, narracja prowadzona jest w 3. os. 1. poj. lub 1. mn., np.: Artomiusz - İ o trzy rzeczy Syná prositá B2; 1. mn; por. A2; Skarga - Nie mniej wielka jej cześć dája Doktorowie Greccy (601).

${ }^{12}$ Te wykładniki językowej obecności nadawcy to tzw. pluralis homileticus (por. Kępka „Trzy kazania o ojczyźnie - ks. Hieronima Kajsiewicza, Jana Pawła II i ks. Jerzego Popiełuszki tradycja i nowoczesność języka" 153-154; tamże literatura). 
Skarga, np. wspominamy [...] wiáry naszej napetnione sprawy [...]; sławim (599), [...] o to sporow nie czynim [...] (604), [...] nie możem [...]; mamy Pośrzedniká [...], ktory jest ubłagániem zá grzechy násze [...]; O Mátko Bogá naszego $[\ldots]$, my osqadzeni $[\ldots]$ przybiegamy $[\ldots]$; wygnanie $[\ldots]$ mamy, ábyś tám o nás mowitá $[\ldots]$; ábyśmy $[\ldots]$ stużyli $[\ldots]$ ábyśmy $[\ldots]$ patrzyli $[\ldots] i[\ldots]$ się $[\ldots]$ ná wieki radowali (605).

W tych kontekstach stosowane są też jednak inne formy. W obu kazaniach, u Artomiusza częściej niż u Skargi, nadawca ujawnia się również w użyciu 1-osobowych form czasownika liczby pojedynczej, dzięki którym duchowny bezpośrednio podkreśla swoją rolę duszpasterza, np.: Artomiusz Niewiem kto owo byt, wiem iż Niewiástá, imienia nie wiem, Niewiástá mowie [...] (A verso), Tedyć nie wiem [...] (B4 verso), Zámilczę [...] (C3), [...] mowiem [...] (C4), Ja to telko rzeke [...] (D verso); Skarga - niewiem (600), śię [...] ktániam [...]. Wiem [...] (601). Ponadto, w mowie skierowanej do katolików występują formy zaimka dzierżawczego nasz, co potwierdzają cytowane powyżej przykłady.

Dialog zakłada obecność odbiorcy, w analizowanych tekstach językowymi wykładnikami tej obecności są na ogół czasownikowe formy 2. os. 1. poj. trybu rozkazującego. Realizują one, charakterystyczną dla kazań, impresywną funkcję wypowiedzi. U Artomiusza odnajdujemy wiele takich zwrotów do słuchacza (2 os. 1. poj.), np.: Znajże [...], wiedz żeś niewieczny [...]. A ktemu, iż nie wiesz [...] (B3), [...] bądźże záwsze gotow [...] (B3 verso), Weyrzy $w$ Legendy [...] (C2 verso), Czytaj [...]. Pátrzmyż jáko śię to zgadza [...] (C3). U Skargi formy 2-osobowe są nieliczne, wyekscerpowano zaledwie dwa rozkaźniki: Pátrz jáko ja [...]. Obácz jáko ja [...] (601) i jedną osobową formę zaimka. Ta ostatnia pojawia się kiedy jezuita, po wprowadzeniu słuchaczy w temat kazania, konkluduje: $O$ czym wdźięczno nam bárzo mowić. Boże áby i wam stucháć śię nie przykrzyło (599-600). Impresywna funkcja mowy kaznodziejskiej wzmocniona jest tu czasami użyciem rozkaźnikowych form 1-osobowych liczby mnogiej. Zabieg taki powoduje, że nadawca staje się równocześnie odbiorcą, np. u Skargi: Sprawmy śię z tego, á ná nię śię pożátujmy [...] (600); Stuchajmy [...] (601); Kwápmy się do tej stużby namilszy braciá, do słowá świętego jego. [...] Miejmy [...] pámiętajmy [...] (604); mowmy [...] (605); u Artomiusza, np. [...] na krewność tę hardzie nie kaźmy, ale raczej abyśmy też cząstke z ta Panna mogli mieć, za pomoca Boża usiłujmy (C). Jak już widać powyżej, mówcy stosują też formy adresatywne. Są one w omawianych tekstach jednostkowe i mają na ogół charakter atrybutywny. W początkowym fragmencie tekstu toruńskiego kaznodziei znajdujemy 
bezpośredni zwrot do wiernych: Krześćiánie mili (A verso), u Skargi w dalszej części mowy, cytowane wyżej: namilszy braciá (Skarga 604).

Powyższe przykłady ukazują, że ów dialog nadawcy z odbiorcą w dwóch chrześcijańskich kazaniach jest różnie realizowany. U Artomiusza częściej do głosu dochodzi relacja ja-ty, w której mówca poucza i nakłania odbiorcę do pewnych działań. W obu tekstach pojawia się też ja-wy, wyrażone formą adresatywną oraz łagodne w wydźwięku, ale dzięki zrównaniu się adresata $\mathrm{z}$ nadawcą zdaje się bardziej przekonujące, $m y$. Ta ostatnia relacja dominuje w mowie kierowanej do katolików.

W tekstach podkreśla się też rolę pierwszoplanowego podmiotu, którym w kazaniach jest zawsze Bóg, u Artomiusza np. Niech to Bog sq̨dźi (C3 verso), u Skargi, np. O Boże uczyń [...] (604).

\section{B. JĘZYKOWE ŚRODKI PERSWAZJI}

Badacze języka kazań, wśród językowych wykładników perswazji najczęściej wymieniają słownictwo wartościujące, dyrektywne i tzw. normatywne, zaimki upowszechniające i różnego rodzaju środki artystyczne (np. metafory, porównania, personifikacje) (por. Kępka, „Językowe środki perswazji w polskich kazaniach katolickich od oświecenia do czasów współczesnych (na wybranych przykładach)” 158, Zdunkiewicz-Jedynak, „Leksykalne środki wartościowania w niedzielnych kazaniach radiowych" i Językowe środki perswazji $w$ kazaniu 38-68). Wybór tych elementów języka odnajdujemy również w omawianych tu XVI-wiecznych drukach.

\section{Słownictwo wartościujące i dyrektywne}

W analizowanych kazaniach nie zabrakło oczywiście nazw wartości i ich określeń. Są to głównie nazwy odnoszące się do wartości moralnych i transcendentnych, np. Art. Anioł, błogosłáwiony Owoc (o Jezusie), Duch Swięty, cała fraza - Krystus Jezus stat się nam madrośćia, odkupieniem, poświęceniem, Mátka Boża, Pánna czysta, stug i stużebnic Bożych, Swięći, uczciwość; Skar. Anioły, chwali, czći i zapłaty godna, madrośći Bożej, P. Chrystus jest świátlość świátá, przeczystej Mátki Bożej, przezacnemu Prorokowi, sławi, święte, Wielka uczennica (o Maryi), Zdrowáś petná táski i wiele innych, które - w umiejętny sposób dobrane - pomagają kaznodziei umacniać wiarę i przekonać słuchaczy do działań urzeczywistniających te wartości. Nazwy te nie będą jednak bezpośrednio przedmiotem opisu. Uwaga nasza skierowana będzie na te środki, które bezpośrednio służą obronie głoszonych w kazaniach 
prawd i myśli, pomagają wiernym je przyjąć oraz kreują obraz przeciwnika innowiercy.

Na początku szkicu (patrz pkt. 3A) wspomniano już o czasownikach charakteryzujących postępowanie i myśli przeciwników. Oprócz neutralnych leksemów opisujących różne czynności (Art., np. mowia, pisza, pokładaja, twierdza, wzięli; Skar., np. czynia, mowia), w obu kazaniach chrześcijańskich znajdujemy formy wyrazów wartościujących negatywnie. Artomiusz już w przedmowie utożsamia się z tymi, których lżyć, sromoćić [...] mieli (3). W tym samym miejscu mówi się o tym, jak piętnowany jest Kośćiot miłego Boga, na który Jakie Cálumniae, jákie potwarzy kładtby záwsze zły á nie zbożny Swiát (2). Dalej czytamy o tym, jak przeciwnicy się [...] spierája, jáko śię wadzq [...] uragája, heretykuja (C3 verso). Takie nacechowane negatywnie czasowniki charakteryzują też oponentów w kazaniu Skargi, np. [...] i onę zelżywie wspomináć śmieja [...] i mátki Bożej uczcić nie umieja [...]. á z nas się [...] śmieja [...] (600). W celu wzmocnienia przekazywanych treści często zestawia się w homiliach leksemy nacechowane negatywnie i pozytywnie, pierwsze odnosząc do adwersarzy w wierze, tak jak w cytowanym już przykładzie z przedmowy do kazania Artomiusza, np. Kośćiot milego BOGA (2) - przeciwstawiony mu zly (a niezbożny) Swiat (2); O pierwszym nie watpi nikt między krześćiány. Wtora záś rozni roznie udawájac watpliwość jákaśs o tym czynia (C verso); [...] ná krewność tę hárdzie nie kaźmy ${ }^{13}$, ále ráczej ábyśmy też cząstkę z ta Pánna mogli mieć, zá pomoca Boża usitujmy (C); u Skargi, np. jedno boleść serdeczna wyciska, stuszny gniew ná ty: ktorzy jej czci $i$ zaptáty ná ziemi i ná niebie ujmuja, i onę zelżywie wspomináć śmieja, i dobrodziejki nawyższej ludzkiego rodzáju uszanować, i matki Bożej uczcić nie umieja [...]. [...] nie ucza [...] nie umieją $z$ nas się ánielskich náśládownikow śmieja, iz tę chwate jej szerzym $i$ powtarzamy záwżdy (600). Jezuita przeciwstawia wiedze - niewiedzy innowierców: Niewiedza ci ludzie [...] Niewiedza jáki jest rozum i báczenie tych, co Duchem ś. Pisali [...]. (600) - Wiemy, iż ono pismo [...]. Wiemy, iż tá Ewángelia [...]. Ale té̀ to wiemy, $i z \dot{z}[\ldots]$ (601).

$\mathrm{W}$ celu zdyskredytowania poglądów i wiary przeciwników w obu mowach, oprócz nacechowanych negatywnie leksemów, wykorzystuje się, jak już widać wyżej, negację, np. Wszystko to nie wedtug náuki Duchá Bożego (B verso, Art.); Tedyś i Pánny czystej [...] decret ten nie minąt, iż $i$ tá umárłá sporu nie mász. (B2, Art.); [...] mowi jáko ten, ktory w tej mierze

${ }^{13}$ W SPXVI czasownik ten odnotowano w znaczeniu 'wyrządzać szkodę, powodować stratę, psuć, niszczyć' (149 razy). 
determinowáć nic nie chćiat (o słowach św. Augustyna, C2 verso, Art.). Artomiusz przekonuje słuchacza o tym, co słuszne i co naganne, np. To stowá Biskupá tego, ktory nie pátrzytci ná to, ále [...] rzecz táka májąc (jáko támże stoi) udawa (C verso); pisze też jakby w odpowiedzi na zarzut herezji: [...] Heretykámi nie będziem [...] (C4). U Skargi zabieg ten pojawia się równie często, na przykład gdy autorytatywnie odpowiada na postawione przez siebie pytanie: Jáko w tym śmieja kośćiol wszytek sądzić i jego rozumowi przyganiać? Wiem dlaczego, iż synámi z kościoła tego ktory jest starożytny Apostolski nie są, áni Duchá tego mája, ktory byt w ojcách świętych [...] (601, Skarga); gdy mówi o oddawaniu czci Maryi: grzechu żadnego áni błędu nie mász (600-601, Skarga) i [...] á przedśię wedle pisma onego wiáry i uczynku nie maja [...] (600, Skarga). W ten sam sposób jezuita wykorzystuje leksemy dyrektywne, np. roskázowáć tego i pisáć nie potrzebá [...]. Kto wie i wierzy [...] A tym potrzebá roskazánia, áby mátkę Boża czćili. (600); ále do Chrystusá i używánia jednánia jego, przypráwy nam potrzebá (605).

W cytatach tych pojawiają się również określenia współwyznawców i przeciwników, dla tych pierwszych są to określenia o pozytywnym nacechowaniu, dla drugich o negatywnych konotacjach. Dobierane są tak, by spolaryzować opisywaną rzeczywistość, wprowadzić wyraźne przeciwstawienie my - oni. Skarga stawia się więc w gronie ánielskich náśládownikow (600), dobrych synów (602), odrzucając i piętnując nową religię: á ráczej przy tych ojcách ś. jako dobrzy synowie zostájmy, á świegoty ${ }^{14}$ te nowe, w ktorych wiárá upádtá á státku nie mász: surowie odprawujmy, o cześć śię mátki Bogá naszego i takie ich niewstydliwe przeciw jej i śmiáte szemrania gniewajac (602). Wiara i wiedza to wartości przypisywane u niego Kościołowi katolickiemu: Bo im wiele jásnego pismá [...] ukázujem [...]. Kto wie i wie$r z y[\ldots]$ (600). Za pomocą pozytywnie nacechowanych leksemów wielokrotnie ocenia przekazywane wiernym nauki: Dobrze nabożeństwá pilnowáć, ále téz dobrze ubogim stużyć [...] (602) ${ }^{15}$; Pewniśmy tego, iż [...]. Nie mniejeśmy pewni, iż [...]. Ale to twierdźim [...] Nie możem i tego przeć, co wielcy święći i bárzo stárzy mowia [...]. Stusznie dorozumiewáć śię możem, iż [...], bo to wiele świętych twierdźi (604). W końcowej modlitwie kierowanej do Maryi prosi o wierność: badź nam [...] uproś nam [...] ábyśmy wiernie jemu stużyli (605). O innowiercach jezuita pisze: Ci ludzie [...] Obojá rzecz w nich

\footnotetext{
${ }^{14}$ Rzeczownik jest notowany (5 razy) w kartotece SPXVI (świegot, szwiegot, świekot). Cytaty, pochodzące m.in. z tekstów biblijnych (Biblia Leopolity, Nowy Testament Jakuba Wujka), potwierdzają użycie go w znaczeniu 'gaduła, papla, plotkarz'.

15 Tylko w tym miejscu przysłówka dobrze użyto aż 8 razy.
} 
proznośći petná, z jednej omylnemi, á z drugiej nieroztropnemi bárzo się pokázuja [...]. Ten jej czci tákiej nie dáje, ktory nie wierzy áby Bogá práwego urodzitá. jáko ći pohańcy nurkowie ${ }^{16}(600)$; Kto wie $i$ wierzy [...] bytby glupszym niźli osiel, gdyby rzekt [...] O nierozumie, jákoś ślepy (600); Ci ludzie [...] (601); I nie byt jeszcze żaden herety $\boldsymbol{k}^{17}$ ktory by jej sprzyjat. Znać iż wszyscy z onego żąlłá wężowego pochodza, ktory onej białogłowskiej nodze śidłá stáwia (601) i ostro reaguje w słowach Niech zámilkna potwarzy ich [...] (602).

Artomiusz też oczywiście przypisuje swojemu środowisku wartości pozytywne. Społeczność, do której adresowane jest kazanie, duchowny utożsamia $\mathrm{z}$ wiernymi sługami, np. Mowi tam Pan o wiernych sługách swych, i tych ktorzy przez prawdę stowá jego poświęceni (C) i podobnie jak Skarga podkreśla pewność wypowiadanych sądów, np. [...] tedyć pewna iż przez śmierć skończenie swe wźiełá. (B2), Pewnie, że wszyscy [...] (B3), [...] pewniśmy tego i pewni być mamy [...] (C). Współwyznawców dwukrotnie nazywa krześcijanami, np. lud Krześćiański (A3 verso; por. też cytat wyżej - A verso) i stawia się także razem $\mathrm{z}$ nimi $\mathrm{w}$ gronie grzeszników: my nędzni, grzeszni (B2 verso). Podobnie jak Skarga, charakteryzuje ich raczej przez przeciwstawienie przeciwnikom religijnym. W kazaniu nie znajdujemy również wielu konkretnych określeń dla przeciwników w wierze. Pojawia się neutralne [...] co zá Kátholicum bá wierę Kátholicisimum wiele ich ma? (B4 verso, podobnie por. A3 verso), lekko nacechowane wyrażenie, znane też z homilii Skargi, np. [...] ktoremi ci ludzie [...] Pánnę tę z Krystusem Pánem porownáć [...] usiłują? (A4), ale też negatywnie wartościujące określenie $\boldsymbol{z}$ łym ludem (B verso). Jednak nauki przez nich głoszone są wartościowane wyraźnie negatywnie. Gani się na przykład ich niewiedzę [...] niechby za to, ci co rzeczy takie twierdza i pisza, odpowiedzieli [...] (B2verso, por. też cytat wyżej B verso), a ich poglądy na omawiany w kazaniu temat nazywa [...] nowe jakieś rewelacje [...] (C2). To, co mówi, Theologia Rzymska odpiera, przeciwstawiając ją autorytetowi Biblii i słowom Apostoła (B). W opisie

\footnotetext{
${ }^{16}$ Człon rzeczownikowy tego wyrażenia notowany jest w SPXVI. Znajdujące się tam hasło norek, z niewielką frekwencją 25 wystąpień, w tym znaczeniu (2.) zarejestrowano ze źródeł zaledwie 2 razy. To 'nazwa nadawana przez katolików zwolennikom odłamu reformacji powstałego w XVI w. w Szwajcarii, Niemczech i Holandii udzielających chrztu dopiero dorosłym przez zanurzanie i stających w opozycji zarówno do kościoła katolickiego, jak i do zinstytucjonalizowanych form reformacji luterskiej i kalwińskiej; anabaptysta [...] nowokrzczeniec' (SPXVI 18: 495).

${ }^{17}$ Leksem w XVI-wiecznej polszczyźnie w użytym tu znaczeniu - 'twórca lub wyznawca twierdzeń religijnych, wywodzących się z chrześcijaństwa, niezgodnych z nauką Kościoła rzymsko-katolickiego' [sic!] - miał wysoką frekwencję (1247 razy), co jest oczywiście śladem i dowodem ożywionej polemiki religijnej// spxvi.edu.pl/indeks/haslo/54572 (dostęp: 15.10.2018).
} 
katolików uwypukla się m.in. próżność i pychę. Cechy przypisane cesarzom rzymskim w zdaniu: Ktora dumá iż nie jednemu (ále prożno) we tbie cwatátá $i$ cwała $^{18}$, Historie świácza $\mathrm{w}$ dalszym wywodzie duchowny odnosi m.in. do papieży: Jáko i dziś mátoli tákich, tesz i ná stotku Piotrowym w Rzymie siedzacych, co się o to nie gniewája, gdy je Bogámi nazwiesz (B2 verso). Myśl ta ulega dalej wzmocnieniu dzięki użyciu formy wołacza i negatywnie nacechowanych epitetów: O nędzni Bogowie. O nędzna glino (B2 verso). Artomiusz wytyka katolikom błędy religijne za pomocą leksemów znanych XVI-wiecznej polszczyźnie i używanych w polemikach religijnych. Kult Maryi nazywa nacechowanym negatywnie rzeczownikiem bałwochwalstwo ${ }^{19}$ (5x), w sąsiedztwie którego pojawić się może tak samo nacechowany przymiotnik, np. srogie batwochwalstwo (A3 verso), o oddawaniu jej czci równej Bogu mówi dobitnie Wszystko to batwochwalstwo, batwochwalstwo, ktore oprócz innych miejsc, Krystus Pan burzy [...]. Więc i one chwasty [...] ktore dnia tego lud pospolity [...] do Kościoła przynosi, [...] do batwochwalstwa i profanatiej imienia Bożego sq (A4verso-B) (por. Kamper-Warejko, „Treściowe i językowe wykładniki podejścia do kultu Maryi w protestanckim kazaniu na święto Wniebowzięcia NMP (Artomiusz 1595)").

Mówcy używają też zaimków upowszechniających, szczególnie wszystek (Artomiusz)/ wszytek (Skarga). Ten zabieg perswazyjny, wywołujący poczucie przynależności do ogółu, wykorzystano w kazaniach w następujących kontekstach, u Artomiusza np.: [...] nas wszystkich [...] (A3), postanowiono wszystkim ludziom (B verso), [...] woła ná nas Duch $S$ [...] przez Ezáiaszá ná wszystkie á wszystkie, nie szeptem, ále głosem wielkim krzyczy [...] (B3). Ostatni przykład pokazuje też, jak dzięki wykorzystaniu dwóch bliskoznacznych czasowników - woła i krzyczy - kaznodzieja stopniuje napięcie. Piotr Skarga w swoim kazaniu pisze, np. o Maryi [...] pilno nam we wszytkim stużyłá [...] pozna [...] wszytko stworzenie [...] (599), [...] prawdźiwa mátka wszech żywiacych [...] (601). Zaimek ten pojawił się też w innych kontekstach, za jego pomocą autor podkreśla zarówno powszechność Kościoła katolickiego: Jáko w tym śmieja kościot wszytek sądzić [...] błogosłáwić będa wszytki narody [...], jak i zakres osób z tego Kościoła wykluczonych: [...] Znáć iż wszyścy z onego żądła wężowego pochodza [...]. (601). Wprowadza

${ }^{18}$ SPXVI od hasła cwałać odsyła do czwałać. Czasownik ten z niską frekwencją (6) występował w XVI-wiecznej polszczyźnie w znaczeniu 'tkwić, grzęznąć' [podkr. aut. JKW].

${ }^{19}$ Pod hasłem batwochwalstwo SPXVI odnotowuje z dużą frekwencją (131) znaczenie: a. 'w polemikach religijnych katolików z innowiercami obelżywe przezwisko nadawane przez przeciwników zwalczanym odłamom chrześcijaństwa: fałszywa wiara, błędy religijne, odszczepieństwo, kacerstwo, herezja'. 
je również $\mathrm{w}$ zdaniach nakłaniających do określonych postaw i przekazujących pewne sądy, np.: Obejrzymy śię ná ty ták święte [...] i od wszytkiego świátá uczczone Doktory [...] (602), Práwo jest pospolite, iż się wszyscy w grzechu rodza [...] (604).

\section{Środki stylistyczne}

Obaj duchowni posiłkują się w swoich mowach takimi środkami artystycznymi, jak pytania retoryczne, powtórzenia, przeciwstawienia i metafory. Część z nich zilustrowano już w podanych powyżej cytatach. Oto wybrane przykłady użytych w tekstach pytań retorycznych, np. Artomiusz - B3, C2 verso, C3; Skarga - áleć oto dbáją? czemu z námi tego nie czynia co Anioł? (600); A nam co ná tym? (604, por. też 603). Dzięki wykorzystaniu przez kaznodziejów powtórzeń, często wplecionych w pytania retoryczne, wzmacniają oni wypowiadane sądy i uwypuklają główne myśli. Oprócz przytoczonych już wyżej przykładów można podać jeszcze inne, u Artomiusza np. Pismo S. [...] uczy nas Wiáry i owocow wiary: záleca nam Wiárę i owoce jej (D verso); u Skargi: Komuż tu krzywdá? [...] Komuż krzywdá, iż [...] Ale krzywdá mowia, Synowi Bożemu [...]. Oto nie krzywdá... (601). Trzeba tu jeszcze podkreślić, że w homilii wybitnego kaznodziei, jezuity Piotra Skargi odnaleźć można wiele paralelizmów, które rytmizują tekst i czynią go łatwiejszym w odbiorze. Próbkę takich zabiegów ilustrują cytowane już przykłady.

\section{TATARSKI TEFSIR}

Leksyka i frazeologia o charakterze perswazyjnym jest obecna także w tatarskich tefsirach. Tu również można wskazać dialogiczność wyrażającą się w zwrotach do adresata i tworzeniu opozycji my - oni. Jej wykładnikami są: formy 2. os. 1. poj. lub mn. trybu rozkazującego, np. nasladūjce jōy (w. 2), pōklōnce śe (w. 10), preč winiz (w. 17); formy optatywu, np. nex ne benze w sercū twojim za trudno (w. 1), nex pōceče na nas z wodi rajškej (w. 48) oraz zaimki osobowe i dzierżawcze, np. prōrōci bōga našeg $\overline{\boldsymbol{o}}$ (w. 51), piśmō naše (w. 38), m̄̄ pewne naleźlișmi tō cō ōbecūwal nam būg naš wšitkō prawziwe wī tež či naleźlișce cō deklárōwal būg waš (w. 42), wigūbiliśmi $\overline{\boldsymbol{x}} \boldsymbol{x}$ $i$ prišla na nix kerane (w. 3), wī ne te lüze ktūre prişengaliśce nam musulmanōm (w. 47), etc. Na tefsirowych kartach obecne jest także słownictwo wartościujące i dyrektywne, w tym liczne pary przeciwstawnych pojęć, np. werōncim mus̀ulmanōm (w. 1), lüzi grešnix (w. 36), i zawolajōy 
ōbiwatele rajśḱe na ōbiwateli peḱelne (w. 42), mezi dobrimi a peḱelnimi zaslōna (w. 44); zaimki upowszechniające, np. ōbecūwal nam būg naš wšitk $\overline{\boldsymbol{o}}$ prawziwe (w. 42), jak również środki artystyczne, zwłaszcza porównania i metafory, $\mathrm{w}$ tym hiperbole, np. takìm trūdnō benze prejśc jakō werblōndōwi w zūrke igelnōy (w. 38), bela 'amūda na ūuka dō peskegōo ščekana prirūwnana (w. 175), takōwe lūze wlaśne jakō bidlō čworōnōge albō ješče ōnī blendnejše za bidlō takōwe lūze ōnī sōy zapamentali ōplōšne (w. 178). Wśród środków leksykalnych można wyróżnić cały szereg nazw czynności, których agensami są poganie i innowiercy, np. takōwe lüze ktūre

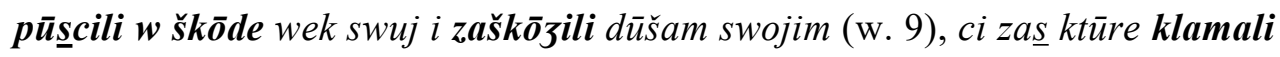
pișmō naše i pōdnesli śe w pixe (w. 34), tix ktūre ōdbijali ōdwozili werōncix $\bar{o} \bar{d}$ drōgi bōžej wjerī mușulmanśkej xcōnc jōy dō śebe i blendūw swojix nakriwic (w. 43) oraz kar, które ich spotkają, np. wigūbiliśmi ìx i prišla na nix kerane naše srōge $w$ nōci albō ōnī bilī snem zmōren̄̄ (w. 3), pricisneliśmi ōbiwatelūw tix mjest napaścami i bedami (w. 92), i zeslalismi nad nimi kerane naglej śmerci ż neba (w. 162). Ponadto wyrażono expressis verbis stosunek Absolutu do niewierzących, np. ōn ne lübi zbitḱi činōncix (w. 29), ōn barzō ne lübi prikezane lamōncix (w. 53). Całość zaś jest skontrastowana $\mathrm{z}$ postępowaniem wiernych, np. ōznajmūjemi pișmō naše dla lū̧̄ ūčōnix wedomix (w. 30).

Spośród wykładników językowych szczególne miejsce zajmują jednak nominacje innowierców i pogan, w które obfituje tatarski zabytek. Wybrane translaty zestawiono $\mathrm{z}$ oryginałem arabskim celem wskazania funkcji perswazyjnej tefsirowego tłumaczenia.

W Koranie obecne są zatem takie nazwy jak ${ }^{20}$ : ar. zālim ${ }^{21}$, wobec którego tatarscy tłumacze używają odpowiedników kriwdniki (sōbe) (w. 4), kriwdniki (samix śebe) (w. 18), zalimi newerniki (w. 39), kriwdniki i newerniki (w. 42), kriwdniki (śebe) (w. 147). Ar. zālim w stopniu wyższym eksplikują jako strukturę heterogeniczną goršij żalimin (w. 35), natomiast połączenie ar. qawm ${ }^{22}$ + ar. zāalim oddają jako te lüze zalimi kriwdniki (w. 149). Ar. rzeczownik kāfir ${ }^{23}$ przekładają jako newerniki (w. 35), natomiast wyrażenia ar. bi-(a)1āhirati kāfirūna 'niewierzący w ostateczność' jako sondū bōžemu newerniki (w. 43) i ar. qawm + ar. kāfir jako lūzì newerne (w. 91). Spośród innych ko-

\footnotetext{
${ }^{20}$ Arabskie źródłosłowy są sprowadzane do 1. poj., czyli haseł słownikowych. Natomiast ich odpowiedniki są przytaczane zgodnie z kontekstem tefsirowym.

${ }^{21}$ I. 'niesprawiedliwy, tyrański, surowy, srogi'; II. 'tyran, despota' (Danecki i Kozłowska 513).

22 1. 'ludzie, naród, plemię'; 2. 'rodacy’ (Danecki i Kozłowska 612).

23 'niewierny, poganin, niewierzący, giaur' (Danecki i Kozłowska 616).
} 
ranicznych nomen można wymienić: ar. safîh ${ }^{24}-\mathrm{u}$ Tatarów glüpci (w. 154), ar. qirda ${ }^{25}$, którego translatem są bestije (w. 166), ar. ğahil ${ }^{26}$, czyli pōgane bōga neznajōnci (w. 198), ar. insān ${ }^{27}$, tj. lūze grešni (w. 36). Na kartach Koranu liczne są też formy imiesłowowe, np. od ar. ağrama (por. pl muğ 'rimūna 'popełniający przestępstwo') ${ }^{28}$, który Tatarzy oddają jako grešniki kriwdniki newerniki (w. 38), grešniki (w. 82), zwodniki prikezane lamōnci (w. 84), a w połączeniu z arabskim qawm jako lūd grešni kerane gōdni (w. 130), od ar. hasira (por. pl ḩāsirūna 'stratni') ${ }^{29}$, który przekładają jako škōdniki (w. 90), škōdniki (samix śebe) (w. 177), škōdniki stracōne (w. 22), a połączenie ar. qawm + ar. hāāsirūna jako lūze škōdliwe (w. 97), od ar. afsada (por. pl muf'sidūna 'zdemoralizowani, zepsuci') $)^{30}$, który thumaczą jako prikezane lamōnci (w. 138) lub zwozicele prikezane lamōnci (w. 101), od ar. iftarà (por. pl muf'tarūna 'wymyślający kłamstwa') ${ }^{31}$, który transponują jako klamliwi falš winajdūjōnci (w. 151), od ar. asrafa (por. pl mus'rifūna 'rozrzutni') (2) $^{32}$ jako zbitḱi činōnce (w. 29), od ar. gafala (por. pl ḡāfilūna 'ignorujący') 33, który eksplikują jako ōplōšne (w. 132, 144) lub zapamentali ōplōšne (w. 178). Podstawą translacji są też verba ${ }^{34}$, np. ar. istakbara ${ }^{35}$, oddawane jako pišne (w. 46), pišne newerniki (w. 73), pišne garde (w. 74), pišne a newerne (w. 86), ar. kaddaba ${ }^{36}$ tłumaczone jako klamliwi (w. 94), ar. fasaqa ${ }^{37}$ przekładane jako nestatečni prikezane lamōnci (w. 163), wistempni s prikezane (w. 165), stąd

${ }^{24} 1$. 'głupi, głupkowaty, idiotyczny, kretyński’; 2. 'bezczelny, bezwstydny’ (Danecki i Kozłowska 421).

25 'małpa' (Danecki i Kozłowska 596).

${ }^{26}$ Por. ğahila 1. 'nie wiedzieć, być nieświadomym, nie mieć pojęcia, nie umieć czegoś';

2. 'być głupim, ciemnym, zachowywać się w głupi sposób’ (Danecki i Kozłowska 266).

27 'człowiek' (Danecki i Kozłowska 107).

28 1. 'popełniać przestępstwo'; 2. 'krzywdzić kogoś' (Danecki i Kozłowska 31).

29 1. 'stracić, utracić'; 2. 'zgubić się' (Danecki i Kozłowska 317).

${ }^{30}$ 1. 'psuć, demoralizować, deprawować’; 2. 'siać waśnie, niezgodę'; 3. 'korumpować' (Danecki i Kozłowska 85).

31 1. 'wymyślać, zmyślać, fabrykować'; 2. 'rzucać oszczerstwa, kalumnie' (Danecki i Kozłowska 84).

32 'marnotrawić, tracić (pieniądze), trwonić, być nieumiarkowanym, szafować' (Danecki i Kozłowska 65).

33 'nie zwracać uwagi, nie zauważać, ignorować' (Danecki i Kozłowska 555).

${ }^{34}$ Przekładane z fakultatywnie występującym łącznikiem być.

${ }^{35}$ Por. 'być dumny, arogancki'.

36 1. 'nazywać kłamcą, oskarżać o kłamstwo'; 2. 'nie wierzyć, nie dawać wiary’; 3. 'przeczyć, zaprzeczać, odrzucać' (Danecki i Kozłowska 620).

${ }^{37}$ 1. 'zbaczać z drogi'; 2. 'oddawać się rozpuście, prowadzić rozpustne życie' (Danecki i Kozłowska 572). 
ar. fāsiq ${ }^{38}$ eksplikowane jako lōtrōwe prikezane lamōnci (w. 100, 142), ar. la 'iba ${ }^{39}$ transponowane jako igriskami rōbōtami zabawne (w. 96), ar. 'amila ${ }^{40}$ przekładane jako činōnce zle ūčinḱi (w. 145), ar. 'amiya ${ }^{41}$ oddawane jako slepe (w. 62). Ponadto przedmiotem eksplikacji są ar. konstrukcje: kāna ${ }^{42}+$ nafs $^{43}+$ hum $^{44}+$ ẓalama $^{45}$, tłumaczone jako ōnī bilì dūšam swojim kriwdnikami (w. 160), nafs + hum + kāna + zalama jako swojim dūšam gwaltōwnikami (w. 176), a kāna + zalama jako nominacje synonimiczne bilī kriwdnikami newernikami (w. 162). Jak wynika $\mathrm{z}$ wyżej przytoczonych kontekstów tatarscy translatorzy - poza tłumaczeniem arabskiej podstawy źródłowej - uzupełniają tefsirowy przekaz o pejoratywne nominacje osób niewierzących - por. škōdnik (w. 22), klamliwij (w. 35), grě̌ni (w. 36), kriwdnik newernik (w. 38), newernik (w. 42, 73, 99, 162), gardi (w. 74), prikezane lamōnci (w. 84, 100, 142, 163), zwozicel (w. 101), kerane gōdni (w. 130), wimōwni žid (w. 173), blōnzōnci newernik (w. 174), pōganin (w. 198) etc.

Reasumując, ar. rzeczownik zālim ma kilka odpowiedników. Są to: krzywdnik, niewiernik i gwałtownik (w niektórych kontekstach tworzą szeregi synonimiczne). Ponadto oddawany jest za pomocą struktur heterogenicznych, hybrydowych, np.: zalim newiernik, gorszy zalimin, zalim krzywdnik. Imiesłów czynny od ar. czasownika ağrama ma trzy odpowiedniki: grzesznik, grzeszny i zwodnik. Jednak tatarscy thumacze zestawiają z nim nominacje krzywdnik, niewiernik lub dodają wyrażenia przykazanie łamiacy i karania godny. Ar. czasownik istakbara oddawany jest jako ${ }^{46}$ pyszny, niewierzacy lub przez zestawienie odpowiedników synonimicznych pyszny gardy, pyszny a niewierny albo przez wyrażenie pyszny niewiernik. Imiesłów od ar. hasira ma odpowiedniki szkodnik, szkodliwy oraz szkodnik stracony, co intensyfikuje jego znaczenie. Imiesłów od ar. fasaqa tłumaczy się jako niestateczny, wystepny, ale z dopowiedzeniami: z przykazania lub przykazanie łamiacy. Imiesłów od ar. afsada to przykazanie tamiacy i zwodziciel przykazanie tamiacy. Translatami ar. kāfir są niewiernik i niewierny. Inne podstawy trans-

\footnotetext{
${ }^{38}$ I. 'rozpustny, niemoralny, zepsuty'; II. 'cudzołożnik, rozpustnik' (Danecki i Kozłowska 561).

39 1. grać'; 2. 'bawić się’ (Danecki i Kozłowska 639).

40 1. 'robić, czynić, działać'; 2. 'wykonywać, produkować'; 3. 'realizować'; 4. 'dążyć, zmierzać, starać się, próbować' (Danecki i Kozłowska 544).

${ }^{41}$ 1. 'oślepnąć, stracić wzrok'; 2. 'być ślepym' (Danecki i Kozłowska 544).

42 'być' (Danecki i Kozłowska 616).

43 'dusza' (Danecki i Kozłowska 761).

44 'oni' (Danecki i Kozłowska 776).

45 1. 'być niesprawiedliwym, krzywdzić kogoś, źle traktować kogoś'; 2. uciskać, tyranizować' (Danecki i Kozłowska 515).

${ }^{46}$ Fakultatywnie z łącznikiem być.
} 
lacji mają $\mathrm{w}$ tatarskim tefsirze jeden ekwiwalent $\mathrm{w}$ postaci nominacji jednowyrazowych ${ }^{47}$, np. ar. kaddaba klamliwy, ar. safīh głupiec, ar. qirda bestia, ar. 'amiya ślepy lub wielowyrazowych, np. ar. imiesłów pl mus'rifūna to zbytki czyniacy, ar. insān to ludzie grzeszni, ar. la'iba to igrzyskami robotami zabawni, ar. 'amila to czyniacy złe uczynki, imiesłów od ar. iftarà to kłamliwi fatsz wynajdujacy, a ar. ğahil to poganie boga nieznajacy, ar. făsiq to totr $\mathrm{z}$ dopowiedzeniem przykazanie tamiacy.

$\mathrm{W}$ ar. oryginale obecne są też wyrażenia i zwroty, np. ar. șāḥib ${ }^{48}+$ ar. nār ${ }^{49}$ przekładane jako tōwaristwo peḱelne (w. 34), lūze peḱelni (w. 48), óbiwatele peḱelne (w. 42); ar. qawmun mus'rifūna 'ludzie występni' tłumaczone za pomocą połączenia lüze zbitḱe činōnce (w. 79); ar. țā'ifatun ${ }^{50}+$ $\operatorname{lam}^{51}+\bar{a}^{2} \operatorname{lana}^{52}$ eksplikowane jako lüze newerōnce (w. 85); ar. kāna + ar. kasaba $^{53}$ transponowane jako bili grex zarabjejōncimi (w. 94); ar. qawm + ar. ğahila oddawane jako lüd bezzakōnnij (w. 134); ar. fa-baddala alladīna zalamū minhum qawlan 'a ci, którzy czynili niesprawiedliwość zmienili słowo' jako te ktūre kriwdnici bilī ż nix i nedōwerḱ̉ slōwu bōže (w. 162).

Już oryginalny tekst Koranu zawiera liczne wykładniki perswazji. Można do nich zaliczyć m.in. reduplikacje obecne na każdym z poziomów języka, w tym leksykalno-semantycznym. W odniesieniu do niewiernych używa się zatem określonego repertuaru powtarzających się nazw. Tatarscy tłumacze podejmują wysiłek oddania środków językowo-stylistycznych oryginału, co przejawia się m.in. w powtarzaniu tych samych nominacji, zestawianiu form synonimicznych (często o znaczeniu pejoratywnym), dodawaniu odpowiedników nieobecnych w oryginale, ale wzmacniających przekaz, np. co kilka wersów wstawiają wyrażenie przykazanie tamiacy. Wszystkie te zabiegi służą intensyfikacji treści.

Wśród leksyki nominującej grzeszników obecne są takie leksemy, jak: bestia, gardy, głupiec, grzesznik, krzywdnik, kłamliwy, niestateczny, niewiernik, opłoszny, [pyszny, szkodnik, ślepy, występny (Kartoteka SPXVI)]. W znakomitej większości są one notowane przez SPXVI w odniesieniu do osób

\footnotetext{
${ }^{47} \mathrm{~W}$ przypadku czasowników może wystąpić łącznik być.

48 'przyjaciel, towarzysz, kolega, współuczestnik, współtowarzysz'; 'zwolennik, poplecznik'; 'właściciel, pan, władca, posiadacz, zarządca, gospodarz' (Danecki i Kozłowska 461).

49 'ogień' (Danecki i Kozłowska 742).

50 1. 'niewielka ilość, trochę'; 2. 'grupa ludzi (zwłaszcza społeczność religijna, gmina wyznaniowa)' (Danecki i Kozłowska 500).

51 'nie' (Danecki i Kozłowska 642).

52 'wierzyć' (Danecki i Kozłowska 19).

${ }^{53}$ 1. 'zwyciężać'; 2. 'zarabiać, zyskiwać, czerpać zyski, korzyści, zdobywać'; 3. 'osiągać' (Danecki i Kozłowska 622).
} 
niewierzących bądź adwersarzy religijnych. Spośród nich wyróżniają się takie nominacje, jak: bestia (SPXVI 2: 49), gardy (SPXVI 8: 308-311 - hardy), grzesznik (SPXVI 8: 216), gwattownik (SPXVI 8: 255-256), krzywdnik (SPXVI 9: 343), niestateczny (SPXVI 18: 83-84), niewiernik (SPXVI 18: 223-225), oploszny (por. SPXVI 21: 409). Bestia to wyraz nacechowany por. 'wyraz obelżywy z odcieniem lekceważenia, pogardy, wstrętu, nienawiści itp.' (a. o człowieku lub zbiorowości ludzkiej) używany nie tylko wobec ludzi bezbożnych, ale też $\mathrm{w}$ polemikach religijnych w odniesieniu do innowierców (np. w CzechEp ${ }^{54}$ ). Gardy w znaczeniu 'pyszny, dumny, wyniosły, zarozumiały; zuchwały, krnąbrny, nieposłuszny, zaczepny, wyzywający, napastliwy' odnosi się m.in. do postawy wobec Boga (por. BiałKat) i jest używany jako atrybut heretyków. Grzesznik w znaczeniu 'człowiek przekraczający przykazania boże lub kościelne’ jest nominacją o chrześcijańskiej proweniencji. Krzywdnik jako 'ten, kto wyrządza komuś krzywdę, krzywdzący kogoś' jest notowany tylko raz w Sandecki-Malecki Mt 5, 44. SPXVI podaje również informację o braku tego hasła w Słowniku Lindego. Niestateczny jest to wyraz używany na kartach Pisma Świętego m.in. wobec tych, którzy zmieniają słowo Boże i prowadzą siebie oraz innych ku zatraceniu por. BudNT 2 P 3,16, WujNT 2 P 3,16. W dobie średniopolskiej poświadczone są też jego użycia w znaczeniu 'nieprawy, złych obyczajów, nierządny' - por. Leop Thren 1, 8, WujJud 217v, BielŻyw. Niewiernik to nominacja znana z Biblii i polemik religijnych, używana z wysoką frekwencją (221 razy) w znaczeniu 'odszczepieniec, bezbożnik, niedowiarek'. Opłoszny to w tatarskim tefsirze wyraz ruskiego pochodzenia - por. brus. оплошенство 'błąd, przeoczenie' i ros. оплошный 'błędny, mylny; nieudany, niefortunny; bezowocny, daremny'. W SPXVI jest notowane hasło płochy 'niestały, nierozważny, niepoważny, lekkomyślny'.

Tatarski tefsir obfituje również w wyrażenia, np. zbitḱi činōnce, tōwaristwo peḱelne, lūze grešni, ōbiwatele peḱelne, sondū bōžemu newerniki, lūze peḱelni, lūze zbitke činōnce, zwodniki prikezane lamōnci, lüze newerōnce, lū̧̄i newerne, grex zarabjejōnce, lūze škōdliwe, lōtrōve prikezane lamōnci, zwozicele prikezane lamōnci, lūd grešni kerane gōdni, lūd bezzakōnnij, prikezane lamōnci, činōnce zle ūčinkí, klamliwi falš winajdūjōnci, dūšam swojim kriwdniki, nedōwerḱi slōwu bōže, wimōwni žid, blōnzōnci newernik, swojim dūšam gwaltōwniki, zapamentali ōplōšne, pōgane bōga neznajōnci. Stanowią one oryginalne połączenia wyrazowe, często o charakterze metaforycznym. Należą do frazeologii koranicznej i z reguły nie są notowane w SPXVI.

\footnotetext{
${ }^{54}$ Odwołując się do egzemplifikacji ze SPXVI, zastosowano skróty źródłowe używane w słowniku.
} 
Wyjątki stanowią, np. ludzie grzeszni, ludzie niewierni, lud grzeszny. Warto dodać, że obecne w nich rzeczowniki i przymiotniki są nominacjami pogan bądź odszczepieńców. Spośród nich wyróżniają się: bezzakonny (SPXVI 2: 82), gwattownik (SPXVI 8: 255-256), lud (SPXVI 12: 321-343), tamiacy (SPXVI 12: 465-466), totr (SPXVI 12: 575-577), niedowiarek (SPXVI 17: 255), poganin (SPXVI 26: 137-142). Bezzakonny to wyraz używany w dobie średniopolskiej z niską frekwencją (12 użyć) w znaczeniu 1. 'nie mający, nie (u)znający, pozbawiony prawa bożego, pisanego' a. o zbiorowości ludzkiej, narodach. Potwierdzony w przekładach Biblii na język polski, np. BudNT 1 Kor 9,21, WujNT 1 Kor 9,21 i 11,21 oraz jako 'przekraczający prawo Boże, nieposłuszny prawu, występny, niesprawiedliwy' u BudNT 1 Tym 1,9. Gwałtownik 1. 'dokonywający przemocy; grabieżca, rozbójnik, rabuś' jest w dobie średniopolskiej używany $\mathrm{w}$ znaczeniu przenośnym 'ten, który tendencyjnie lub fałszywie interpretuje', np. w SeklWyzn, LubPs, CzechEp, RejAp, gdzie tworzy wyrażenia gwałtownik słowa bożego (pańskiego), testamentu (bożego) oraz 2. 'postępujący wbrew przyjętym normom prawnym lub moralnym', np. w BibRadz 1 Tym 1,13, WujNT 1 Tym 1,13, Bud Bib Eccli 29,24 czy BielKron, RejPos. Lud jest w tłumaczeniach Biblii używany w znaczeniu 'wyznawcy innych bogów' (np. Leop 2 Par 32, 14, BibRadz 2 Par 32,15, BudBib 2 Par 25,15). Eotr to w dobie średniopolskiej nominacja innowierców. Jest to wyraz nacechowany i występuje w znaczeniu 'człowiek żyjący niezgodnie z uznanymi nakazami dobrych obyczajów i moralności; łajdak, niegodziwiec; rabuś, zbój, złoczyńca'. Łamiący to wyraz używany z niską frekwencją ( 8 razy). W znaczeniu 'postępujący wbrew czemu' odnosi się do łamania wiary (ModrzB). Niedowiarek to m.in. 'człowiek o słabej wierze, który częściowo neguje lub całkowicie odrzuca zasady religii' (np. Leop Ez 2,6, BibRadz Rz 3,3, BielKron, RejAp, RejPos, WujNT Łk 1,17), a także 'poganin' (np. RejPos, BiałKat, SkarŻyw). Poganin to 'wierzący w nieprawdziwego Boga (lub bogów); termin, jakiego używają wyznawcy jakiejś religii w odniesieniu do innowierców', także 'muzułmanie o wyznawcach innych religii, zwłaszcza chrześcijanach' (np. MiechGlab, BielKron) oraz 'obraźliwie o przeciwnikach religijnych'.

\section{WNIOSKI}

Polemiczne teksty religijne trzech konfesji: katolicyzmu, protestantyzmu i islamu wpisują się w nurt piśmiennictwa reformacyjnego o charakterze per- 
swazyjnym. Obfitują w wykładniki językowe o funkcjach impresywno-ekspresywnych. Realizują uniwersalne cechy kodu religijnego, takie jak otwartość i polisemia, które wyrażają się przez analogię, porównanie, metonimię, metaforę, mówienie poza asercją. Słownictwo wyspecjalizowane zyskuje tu dodatkowe wsparcie w postaci leksyki nazywającej wartości, a także słownictwa wolitywnego, nakłaniającego, perswazyjnego oraz emotywnego, z wyraźnym odniesieniem dychotomicznym do tego, co dobre i złe. I choć samo wywieranie wpływu nie może być oceniane jako nieetyczne, to sposób przekazywania treści i wykorzystywane środki służące poniżeniu i deprecjacji przeciwników religijnych mogą już takiej ocenie podlegać. Do modalnych wykładników reformacyjnych tekstów religijnych należą zatem wyrazy i połączenia wyrazowe nazywające w najogólniejszych kategoriach postawę przyjęcia i aprobaty (lub odrzucenia i dezaprobaty) rzeczywistości transcendentnej (por. grupęnomina agentis - wierzących i niewierzących). Wszystkie te składniki razem organizują przestrzeń sakralną tekstu religijnego i są osią, wokół której integruje się grupa wyznaniowa. Reformacja wzbogaciła dyskurs religijny, prowadzony w językach narodowych, o elementy języka naukowego i stylu retorycznego, w tym także słownictwa humanistyki. Dlatego do cech kodu religijnego tego okresu należy zaliczyć, oprócz wspomnianych już cech, także wprowadzanie cytatów z dzieł autorytetów religijnych, tj. głównie Biblii i Koranu (por. wnioski Kulwicka-Kamińska 168-169; Kamper-Warejko, „Treściowe i językowe wykładniki podejścia do kultu Maryi w protestanckim kazaniu na święto Wniebowzięcia NMP (Artomiusz 1595)" 198).

\section{ŹRÓDŁA}

Artomiusz, Piotr. Sermon to jest kazanie na dzień Wniebowzięcia Panny czystej, ktory się co Rok 15. Augusti wraca, Toruń, 1595, (BN, sygnatura Baw.24045).

Skarga, Piotr. Na Dzień Wniebowzięcia Przeczystej Matki Bożej”, Kazania na niedziele i święta całego roku..., Kraków, A. Piotrkowczyk, 1595, (Biblioteka UW 28.1.2.7).

Tefsir z 1723 r. (autorska transliteracja oparta na systemie przyjętym w ramach prac nad projektem „TEFSIR” nr 11H 160319 84).

\section{BIBLIOGRAFIA}

Belcarzowa, Elżbieta. Polskie i czeskie źródła przekładu Biblii Leopolity. „Lexis”, 2006.

Danecki, Janusz i Jolanta Kozłowska. Stownik arabsko-polski. Wiedza Powszechna, 1996.

Drozd, Andrzej. Arabskie teksty liturgiczne w przektadzie na język polski XVII wieku. Zagadnienia gramatyczne na materiale chutb światecznych. DIALOG, 1999. 
Dziekan, Marek. Arabia magica. Wiedza tajemna u Tatarów przed islamem. DIALOG, 1993.

Głowiński, Michał. „Kazanie”. Słownik terminów literackich, red. Janusz Sławiński, Ossolineum, 1998, s. 240.

Hawrysz, Magdalena. Polemiczna twórczość Marcina Czechowica w perspektywie genologii lingwistycznej. Uniwersytet Zielonogórski, 2012.

Kamper-Warejko, Joanna. Pieśni pasyjne i wielkanocne w kancjonale Piotra Artomiusza (Toruń 1601). TNT, 2006.

Kamper-Warejko, Joanna. „Treściowe i językowe wykładniki podejścia do kultu Maryi w protestanckim kazaniu na święto Wniebowzięcia NMP (Artomiusz 1595)". Zielonogórskie Seminaria Językoznawcze. Dyskursy o przeszłości. Dyskursy w przeszłości, Uniwersytet Zielonogórski, 2019, w druku.

Karwat, Mirosław. Podstawy socjotechniki dla politologów, polityków i nie tylko. Difin, 2014.

Kępka, Izabela. „Językowe środki perswazji w polskich kazaniach katolickich od oświecenia do czasów współczesnych (na wybranych przykładach)”. Język - Szkoła - Religia, nr 4, 2009, ss. $152-161$.

Kępka, Izabela. „Trzy kazania o ojczyźnie - ks. Hieronima Kajsiewicza, Jana Pawła II i ks. Jerzego Popiełuszki - tradycja i nowoczesność języka". Tradycja i nowoczesność, red. Ewa Woźniak, Archidiecezjalne Wydawnictwo Łódzkie, 2008, ss. 151-162.

Korolko, Mirosław. Sztuka retoryki. Wiedza Powszechna, 1990.

Koziara, Stanisław. Frazeologia biblijna w języku polskim. Wydawnictwo Naukowe Akademii Pedagogicznej, 2001; wyd. 2 Oficyna Wydawnicza LEKSEM, 2009.

Koziara, Stanisław. Tradycyjne biblizmy a nowe polskie przekłady Pisma Świętego. Ujęcie filologiczno-normatywne. Wydawnictwo Naukowe Uniwersytetu Pedagogicznego, 2009.

Krok, Dariusz. „Etyczne aspekty perswazji w reklamie”, Dialogi o kulturze i edukacji, nr 1(1), 2012, ss. 185-198, serwer1366511.home.pl/dialogi/data/documents/Dariusz=20Krok.pdf. Dostęp 9.02.2020.

Kulwicka-Kamińska, Joanna. Przekład terminologii religijnej islamu $w$ polskich tlumaczeniach Koranu na tle biblijnej tradycji translatorycznej. Wydawnictwo Naukowe UMK, 2013.

Kwilecka, Irena. Studia nad staropolskimi przekładami Biblii. UAM. Wydział Teologiczny; PAN Instytut Slawistyki, 2003.

Lisowski, Tomasz. Sola Scriptura. Leksyka Nowego Testamentu Biblii Gdańskiej (1632) na tle porównawczym. Ujęcie kwantytatywno-dystrybucyjne. Wydawnictwo Rys, 2010.

Meller, Katarzyna. „Noc przeszła, a dzień się przyblizyl”. Studia o polskim stownictwie reformacyjnym XVI wieku. Wydawnictwa Nauk. UAM, 2004.

Okopień-Sławińska, Aleksandra. „Figury retoryczne”. Stownik terminów literackich, red. Janusz Sławiński, Ossolineum, 1998, ss. 154-155.

Okopień-Sławińska, Aleksandra. „Retoryka”. Słownik terminów literackich, red. Janusz Sławiński, Ossolineum, 1998, ss. 472-473.

Podgórecki, Adam. Zasady socjotechniki. Wiedza Powszechna, 1996.

Sambor, Jadwiga. „O języku współczesnych kazań polskich”. O języku religijnym, red. Maria Karpluk, Jadwiga Sambor, Wydawnictwo KUL, 1988, ss. 45-69. 
Styszyński, Marcin. „Apoteoza przemocy w propagandzie Państwa Islamskiego”, Res Rhetorica 2, bazhum.muzhp.pl/media//files/Res_Rhetorica/Res_Rhetorica-r2015-t-n2/Res_Rhetorica-r2015-t-n 2-s16-24/Res_Rhetorica-r2015-t-n2-s16-24.pdf. Dostęp 17.09.2018.

Suter, Paul. Alfurkan Tatarski. Der litauisch-tatarische Koran-Tefsir. Böhlau, 2004.

Tarelka, Mikhas' i Iryna Synkova. Adkul' payshli idaly. Tekhnalogiya, 2009 [Тарэлка, Міхась і Ірына Сынкова. Адкуль пайшлі ідалы. Тэхналогія, 2009].

Winiarska, Izabela. Stownictwo religijne polskiego kalwinizmu od XVI do XVIII wieku na tle terminologii katolickiej. „Semper”, 2004.

Witczyk, Henryk, red. Encyklopedia chrześcijaństwa. Historia i wspótczesność 2000 lat nadziei. Jedność, 2000.

Zdunkiewicz-Jedynak, Dorota. Językowe środki perswazji w kazaniu. „Poligrafia Salezjańska”, 1996.

Zdunkiewicz-Jedynak, Dorota. „Leksykalne środki wartościowania w niedzielnych kazaniach radiowych”. Język a chrześcijaństwo, red. Irena Bajerowa, Maria Karpluk i in., Towarzystwo Naukowe KUL, 1993, ss. 71-84.

Zwoliński, Andrzej. Stowo w relacjach społecznych. WAM, 2003.

\section{PERSWAZJA W CZASACH REFORMACJI. RENESANSOWE TEKSTY APOLOGETYCZNE TRZECH KONFESJI: KATOLICYZMU, PROTESTANTYZMU I ISLAMU}

Artykuł wpisuje się w nurt opisu języka religijnego doby renesansu. Zwrócono w nim uwagę na tematykę literatury reformacyjnej i kontrreformacyjnej (katolickiej), jej wymiar wspólnotowy, mający na celu scalanie wspólnoty wierzących oraz opisano służące temu celowi zabiegi językowe i środki perswazyjne. Bazą materiałową są trzy XVI-wieczne teksty, reprezentujące dwa odłamy chrześcijaństwa - katolicki i protestancki (kazania na dzień Wniebowzięcia NMP Piotra Skargi i Piotra Artomiusza z 1595 r.) i islam (sura Koranu pt. Wzniesione krawędzie w thumaczeniu Tatarów WKL, XVI wiek). Analizie poddano strukturę zabytków, wykładniki dialogiczności oraz językowe środki perswazji, na które składa się m.in. słownictwo wartościujące, dyrektywne i środki stylistyczne. Badania dowiodły, że omówione tu polemiczne teksty religijne wpisują się w nurt piśmiennictwa reformacyjnego o charakterze perswazyjnym. Znajdujemy w nich wykładniki językowe o funkcjach impresywno-ekspresywnych. W warstwie językowej teksty te realizują uniwersalne cechy kodu religijnego, takie jak otwartość i polisemia, które wyrażają się przez analogię, porównanie, metonimię, metaforę, mówienie poza asercją. Omówiono wyekscerpowaną leksykę nazywającą wartości, słownictwo wolitywne i nakłaniające oraz perswazyjne i emotywne, z zauważalnym odniesieniem dychotomicznym do tego, co dobre i złe. Wskazane tu elementy organizują przestrzeń sakralną tekstu religijnego i są osią, wokół której integruje się grupa wyznaniowa. Pokłosiem reformacyjnego dyskursu religijnego jest obecność w polskojęzycznych tekstach wykładników stylu retorycznego, co wyraża się m.in. wprowadzaniem cytatów z dzieł autorytetów religijnych, tj. głównie Biblii i Koranu.

Słowa kluczowe: polszczyzna XVI-wieczna; protestantyzm; język religijny; kazanie; językowe środki perswazji. 


\section{PERSUASION AT THE TIME OF REFORMATION RENAISSANCE APOLOGETIC TEXTS OF THREE CONFESSIONS: CATHOLICISM, PROTESTANTISM AND ISLAM.}

The paper comprises a description of the religious language used in the Renaissance. It addresses the topic of the literature of Reformation and Counter-Reformation (Catholic Revival) periods and its significance as a uniting force for a given community of believers. Moreover, the paper describes the linguistic solutions and means of persuasion used to achieve that purpose. The study material are three sixteenth-century texts: two that originated in two Christian denominations - Catholic and Protestant ones (sermons published by Piotr Skarga and Petrus Artomius on the occasion of the Assumption Feast of Mary the Virgin in 1595) and one that derives from Islam (Surah 7 of the Quran "The Heights" translated by the Tatars of the Grand Duchy of Lithuania, 16th century). The analysis covers the structure of these historical texts, the exponents of dialogue and the linguistic means of persuasion which include, among others, evaluative and directive language as well as stylistic devices. Research has shown that the three religious polemical texts can be classified as persuasive literature of the Reformation. They comprise linguistic exponents with impressive and expressive functions. In the linguistic layer, the texts contain universal features of the religious code, such as openness and polysemy, which are expressed by analogy, comparison, metonymy, metaphor, and making non-assertive utterances. The paper discusses lexis excerpted from the texts and denoting values as well as volitive and imperative and persuasive and emotive vocabulary with noticeable dichotomic references to what is good and what is bad. These elements arrange the sacred space of the religious texts and constitute the axis of integration for a given community of believers. The result of religious discourse of the Reformation is the presence of the exponents of the rhetorical style in Polish texts, which is manifested by the use of quotations from authoritative religious works, i.e. mainly from the Bible and the Quran.

Key words: sixteenth-century Polish language; Protestantism; religious language; sermon; linguistic means of persuasion. 